\title{
Variation in antioxidant activity at two ripening stages of wild mango, Spondias pinnata (L.f.) Kurz., an underutilized fruit
}

\author{
Bince Mani ${ }^{1} \&$ Sinjumol Thomas ${ }^{2^{*}}$ \\ ${ }^{1}$ Department of Botany, St. Thomas College, Palai, Kottayam 686 574, India \\ ${ }^{2}$ Department of Botany, Carmel College, Mala, Thrissur 680 732, India \\ *Email: sunithatom@gmail.com
}

\section{ARTICLE HISTORY}

Received: 09 July 2020

Accepted: 22 August 2020

Published: 01 October 2020

KEYWORDS

DPPH

Flavonoids

India

Phenolics

Radical scavenging

\section{ABSTRACT}

Antioxidant compounds play a significant role in preventing and scavenging free-radicals by reducing oxidative stress and providing protection to humans against degenerative diseases and infections. Obviously, antioxidant molecules of plant origin are pivotal to combat the oxidative harm in cells. Present work intended to evaluate the antioxidant capacity of the fruits of Spondias pinnata. Methanol extracts of the fruits at two stages of maturity were prepared and investigated by various antioxidants analyses such as total antioxidant activity, reducing power and radical scavenging assays (DPPH, nitric oxide and hydrogen peroxide). Its total phenol, flavonoid and tannin contents were also determined. Spondias pinnata fruit extracts exhibited effective antioxidant activity and its $\mathrm{IC}_{50}$ values of the unripe fruits were $65,66,72.23,83.25,66.75 \mu \mathrm{g} / \mathrm{ml}$ and ripe fruits were $124.24,92.50,97.66,144.10,72.25$ $\mu \mathrm{g} / \mathrm{ml}$, for total antioxidant activity, reducing power, DPPH radical scavenging, nitric oxide radical scavenging and hydrogen peroxide scavenging assays respectively. The extracts, especially unripe fruit extract had good amounts of total phenolic and flavonoid contents which might contribute the antioxidant activities considerably. It is evident from the study that the fruits of $S$. pinnata possessed potent antioxidant activity and it can be considered as a good dietary choice among the underutilized fruits as well as common fruits. Therefore, wild mango may be a good choice of antioxidants of plant origin for dietary and pharmaceutical uses.

\section{Introduction}

Free-radicals are a collection of highly reactive molecules that impair the cellular functions by damaging nucleic acids, proteins and lipids $(1,2)$. Free radicals of cellular origin or from outside are one of the major agents for various diseases such as cancer, neurodegenerative diseases, cardiovascular diseases, diabetes and to even ageing (3). Antioxidant molecules (natural and synthetic) are considered as possible means for hindering and treating such diseases. Obviously, most of the synthetic molecules are found to be unsafe due to their possible carcinogenicity and toxicity (4). On the other hand, the intake of fruits and vegetables has a strong hindrance in developing such chronic diseases (5). In most cases, vitamins and secondary metabolites particularly polyphenols are considered to be responsible for such antioxidant activity (6). Studies on antioxidant activities of various fruits, vegetables, spices, medicinal plants and even microalgae have shown the presence of rich amounts of natural antioxidants in them (7-9), Hence, the search for plants containing powerful antioxidants remains to be a focus of investigators.

Wild fruits are gaining increasing attention from pharmaceutical industries because of their nutritional value, vitamin and mineral contents and medicinal properties. With reference to their therapeutic characteristics, the antioxidant potential is the most commonly studied benefits (10). India and other tropical countries have an abundance of fruits in the wild and many of them belong to the underutilized category. Wild mango (Spondias pinnata (L.f.) Kurz.; Anacardiaceae) is such fruit and is mainly distributed in India, Sri Lanka and other southeast Asian countries $(11,12)$. It is chiefly found in the Western Ghats and north-eastern states of India. It is a medium-sized tree found in the

(c) Mani \& Thomas (2020). This is an open-access article distributed under the terms of the Creative Commons Attribution License, which permits unrestricted use, distribution and reproduction in any medium, provided the original author and source are credited (https://creativecommons.org/licenses/by/4.0/).

To cite this article: Mani B, Thomas S. Variation in antioxidant activity at two ripening stages of wild mango Spondias pinnata (L.f.) Kurz., an underutilized fruit. Plant Science Today. 2020;7(4):534-541. https://doi.org/10.14719/pst.2020.7.4.863 
deciduous to semi-evergreen forests and flowers from March to April. The fruits ripen early in November and available up to December $(11,12)$. Unripe fruits are preserved in brine (pickle) and are usually used in culinary preparations such as curries, jams, sherbet and condiments in places where it grows naturally (13). The nutritional value of this fruit is comparable to that of plum, apricot, cherry, peach and mango (12). Different parts of the plant, especially fruits, stem bark, leaves, and roots have been used in conventional medicinal preparations to treat various ailments such as bronchitis, ulcer, dysentery, diarrhoea, vomiting, skin diseases, dyspepsia and muscular rheumatism (14). The stem bark possesses ample amounts of phenolics and flavonoids and has free radical scavenging activities (15, 16) and anticancer properties (17). An early study (18) points out cytotoxic, antimicrobial and anti-inflammatory activities of essential oils obtained from fruit peel. The leaves and raw fruits have reported for its antibacterial, antioxidant (14), free radical scavenging activity and antitumor properties (12). However, no detailed studies of antioxidant and radical scavenging activities of unripe and ripe fruits of this plant from the Western Ghats are available. Hence, the present study is aimed to evaluate the antioxidant activities and to estimate the phenolic, flavonoid and tannin contents at two ripening stages of fruits of S. pinnata.

\section{Materials and Methods}

\section{Collection of fruits and preparation of extract}

The unripe (approximately 60 days after pollination) and ripe (approximately 220 days after pollination) fruits were collected randomly from natural populations of $S$. pinnata growing in the Vellikulam area (altitude 400-700 m) of Kottayam, Kerala, India. A total of 27 unripe and ripe fruits were divided into three replicates $(n=3)$ with nine fruits per replicate. A voucher specimen (RHT65257) has been placed at St. Joseph's College, Tiruchirappalli.

The fruits were brought into the laboratory and washed with distilled water. The pericarp and mesocarp were separated together from seeds of unripe and ripe fruits and subsequently, air-dried for a short time and shade dried at room temperature $\left(29 \pm 3{ }^{\circ} \mathrm{C}\right)$. The dried pericarp and mesocarp were made into a fine powder and methanolic extract was prepared using Soxhlet apparatus ( $65{ }^{\circ} \mathrm{C}$ for $8 \mathrm{hr}$ ) from $100 \mathrm{gm}$ powder. The extracts were concentrated using rotary evaporator (Rotavapor ${ }^{\circledR}$ R-210, BUCHI, Flawil, Switzerland) (temperature $40{ }^{\circ} \mathrm{C}$ and pressure 337 mbar) and kept at $4{ }^{\circ} \mathrm{C}$ for analysis.

\section{Determination of total antioxidant capacity}

Phosphomolybdenum technique was used to examine the total antioxidant capacity of unripe and ripe fruits of $S$. pinnata (19). $3 \mathrm{ml}$ of the reagent solution $\left[600 \mathrm{mM} \mathrm{H}_{2} \mathrm{SO}_{4}, 28 \mathrm{mM} \mathrm{Na}_{2} \mathrm{HPO}_{4} \& 4 \mathrm{mM}\right.$ $\left.\left(\mathrm{NH}_{4}\right)_{6} \mathrm{Mo}_{7} \mathrm{O}_{24}\right]$ was transferred to various concentrations (25 $\mu \mathrm{g}, 50 \mu \mathrm{g}, 75 \mu \mathrm{g}, 100 \mu \mathrm{g}, 125 \mu \mathrm{g} \&$
$150 \mu \mathrm{g})$ of the extract followed by incubation at $95^{\circ} \mathrm{C}$ for $90 \mathrm{~min}$. The mixture was allowed to cool and optical density was measured at $695 \mathrm{~nm}$ (Shimadzu, UV-150-02, Kyoto). Methanol and ascorbic acid were used as blank and reference compound respectively. The percentage total antioxidant capacity was calculated by using the formula:

$$
\left(A_{s} / A_{m}\right) \times 100
$$

Here, $A_{m}$ is maximum absorbance tested, $A_{s}$ is the absorbance of the sample.

\section{Determination of reducing power}

To various concentrations $(25 \mu \mathrm{g}, 50 \mu \mathrm{g}, 75 \mu \mathrm{g}, 100$ $\mu \mathrm{g}, 125 \mu \mathrm{g} \& 150 \mu \mathrm{g})$ of the extract, $0.2 \mathrm{M}$ sodium phosphate buffer (2.5 ml, $\mathrm{pH}$ 6.6) and potassium ferricyanide (5 ml, 1\%) were added. Trichloroacetic acid (5 ml, 10\%) was transferred to the mixture after incubation $\left(20 \mathrm{~min}\right.$ at $\left.50{ }^{\circ} \mathrm{C}\right)$. The reaction mixture was centrifuged and supernatant $(5 \mathrm{ml})$ was mixed with distilled water $(5 \mathrm{ml})$ and ferric chloride $(1 \mathrm{~m}$, $1 \%)$. The optical density was measured at $700 \mathrm{~nm}$. The reducing power of the samples at different concentrations was calculated by using the above formula (i). This method was slightly modified from the earlier described standard method (20).

\section{Radical scavenging assay (1,1- diphenyl-2- picrylhydrazyl, DPPH)}

The free radical scavenging capacity of the samples was analysed using DPPH radical (21). DPPH solution ( $1 \mathrm{ml}, 0.1 \mathrm{mM}$ ) in methanol was added to the sample solution $(25 \mu \mathrm{g}, 50 \mu \mathrm{g}, 75 \mu \mathrm{g}, 100 \mu \mathrm{g}, 125 \mu \mathrm{g} \& 150 \mu \mathrm{g})$ in methanol (3 ml). It was mixed thoroughly and kept in the dark (30 min) and the optical density was measured at $517 \mathrm{~nm}$. DPPH radical scavenging efficacy was calculated using the following formula:

$(\%)=\left(\left(A_{0}-A_{1}\right) / A_{0}\right) \times 100$

where $A_{0}$ and $A_{1}$ are absorbance values of the control and of the test samples respectively. Ascorbic acid was used as reference compound.

\section{Radical scavenging assay (Nitric oxide, NO)}

Griess Illosvoy reaction (22) was done to assess the nitric oxide scavenging capacity of the samples. To various doses (25 $\mu \mathrm{g}, 50 \mu \mathrm{g}, 75 \mu \mathrm{g}, 100 \mu \mathrm{g}, 125 \mu \mathrm{g} \&$ $150 \mu \mathrm{g}$ in $3 \mathrm{ml}$ ) of the sample solution in $10 \mathrm{mM}$ sodium nitroprusside (dissolved in $0.5 \mathrm{M}$ phosphate buffer, pH 7.4), Griess reagent $(0.1 \%$ a-napthylethylenediamine in distilled water and $1 \%$ sulphanilamide in $5 \% \mathrm{H}_{3} \mathrm{PO}_{4}$ ) was added after incubation for $60 \mathrm{~min}$ at $37^{\circ} \mathrm{C}$. The pink chromophore generated during the reaction was measured at $540 \mathrm{~nm}$. Nitric oxide scavenging capacity (\%) was calculated using the above equation (ii).

\section{Radical scavenging assay (Hydrogen peroxide, $\mathrm{H}_{2} \mathrm{O}_{2}$ )}

Hydrogen peroxide radical scavenging was determined according to the standard method described (23). Different concentrations (25 $\mu \mathrm{g}, 50$ $\mu \mathrm{g}, 75 \mu \mathrm{g}, 100 \mu \mathrm{g}, 125 \mu \mathrm{g} \& 150 \mu \mathrm{g}$ ) of the sample were mixed with $0.6 \mathrm{ml}$ of $43 \mathrm{mM}$ (in $0.1 \mathrm{M}$ phosphate buffer, pH 7.4) hydrogen peroxide 
solution. Optical density of the mixture was detected after $10 \mathrm{~min}$ at $230 \mathrm{~nm}$. The inhibition activity (\%) was calculated using the equation (ii).

\section{Total phenolic content determination}

Phenolic contents of the extracts were estimated using Folin-Ciocalteu method (24). A volume of 800 $\mu \mathrm{l}$ Folin-Ciocalteu reagent and $2 \mathrm{ml}$ sodium carbonate $(7.5 \%)$ were added to $100 \mu \mathrm{l}$ of extract. Make the volume (diluted) to $7 \mathrm{ml}$ using distilled water and was kept in dark ( $2 \mathrm{hr})$. The optical density was measured at $765 \mathrm{~nm}$. Gallic acid was used as reference molecule and phenolic content was quantified as $\mathrm{mg}$ gallic acid equivalent (GAE)/100 gm dry weight of the extract (DW).

\section{Total flavonoid content determination}

It was estimated using $\mathrm{AlCl}_{3}$ (25) method and quercetin was the reference molecule. To $0.3 \mathrm{ml}$ distilled water, $100 \mu \mathrm{l}$ extract and $30 \mu \mathrm{l} \mathrm{NaNO}$ (5\%) were added. $30 \mu \mathrm{l}$ of $\mathrm{AlCl}_{3}(10 \%)$ was added to this after $5 \mathrm{~min}$. Finally, $200 \mu \mathrm{l}$ of sodium hydroxide (1 $\mathrm{mM}$ ) was transferred to the mixture after a lapse of 5 min. The test solution was diluted to $1 \mathrm{ml}$ with distilled water before measuring the absorbance at $510 \mathrm{~nm}$. The flavonoid content was quantified as $\mathrm{mg}$ quercetin equivalent (QEE)/100 gm DW of the extract.

\section{Total tannin content determination}

According to Folin-Denis method (26), $50 \mu \mathrm{l}$ of extract was diluted to $7.5 \mathrm{ml}$ with distilled water. To this, Folin-Denis reagent $(0.5 \mathrm{ml})$ and sodium carbonate $(1$ ml) were transferred. Finally, the volume of the mixture was made up to $10 \mathrm{ml}$ by adding distilled water. Optical density was measured at $700 \mathrm{~nm}$. Reference compound used was Tannic acid and tannin content quantified as $\mathrm{mg}$ tannic acid equivalent (TAE)/100 g DW of the extract.

\section{Statistical analysis}

All analysis was performed in three times for each group and results were given as mean $(n=3) \pm$ S.D. and compared by Tukey's HSD tests. The fruit extracts and reference compound providing 50\% inhibition $\left(\mathrm{IC}_{50}\right)$ were calculated from the graph as $\mu \mathrm{g} / \mathrm{ml}$ through the dose-response curve. Results were significant if $P \leq 0.05$. SPSS (Version 22.0) software was used for statistical analysis.

\section{Results and Discussion}

\section{Total antioxidant activity}

The total antioxidant capacity is based on the reduction of Mo (VI) to Mo (V) by metabolites present in the extract and consequently the formation of phosphate/Mo (V) complex at acidic conditions (19). The results of the total antioxidant activity of fruit extracts of $S$. pinnata and reference compound ascorbic acid are depicted in Table 1. The total antioxidant potential of unripe fruits was found to be promising with $\mathrm{IC}_{50}$ value of $65 \mu \mathrm{g} / \mathrm{ml}$ (Table 6), which is equal to that of standard ascorbic acid $(63.25 \mu \mathrm{g} / \mathrm{ml})$. The results also show that there was no significant variation in total antioxidant capacity at $50 \mu \mathrm{g} / \mathrm{ml}$ and $100 \mu \mathrm{g} / \mathrm{ml}$ concentrations of unripe fruit extract and ascorbic acid (Table 1). It was found that the ripe fruit extract required a quantity of $124.25 \mu \mathrm{g} / \mathrm{ml}$ for reducing $50 \%\left(\right.$ IC $_{50}$ ) of Mo (VI) to Mo (V). At the same time a concentration of $125 \mu \mathrm{g} / \mathrm{ml}$ of unripe fruit extracts reduced $82 \%$ of Mo (VI) to Mo (V), i.e. methanol extract of unripe fruits has effective antioxidant potential than that of ripe fruits. The antioxidant activity was given most often by the phenolic compounds in the extracts and this might be reflected in the antioxidant activity of unripe and ripe fruit extracts of $S$. pinnata $(27,28)$. The unripe fruit extract had good amounts of phenolics $(384.24 \pm 0.18)$, which were considerably different from that of mature fruit extract (243.13 \pm 0.29) (Table 7). Similar results were reported in Psidium guajava L. and Nypa fruticans Wurmb (29). In addition to phenolics, flavonoids and tannins have antioxidant potential to a certain extent $(30,31)$.

Phenolics are important phytoconstituents among various natural antioxidants because of their multiple biologic effects and direct contribution to antioxidant activity (27). According to an earlier study (28), the antioxidant activity of fruits and vegetables are most often correlated with the phenolic constituents. Various studies also demonstrated the wide medicinal applications of plant phenolics (32-34).

\section{Reducing power assay}

The methanol extracts of wild mango showed a substantial level of reducing activity. The results of the reducing power of the fruits at two stages of maturity are depicted in Table 2. Reducing capacity of the samples increased with increasing concentrations and significant difference $(P<0.05)$ was observed in reducing power between unripe and ripe fruits with $\mathrm{IC}_{50}$ values of $66 \mu \mathrm{g} / \mathrm{ml}$ and 92.5 $\mu \mathrm{g} / \mathrm{ml}$ respectively. Reference molecule ascorbic acid exhibited IC $_{50}$ values of $41.75 \mu \mathrm{g} / \mathrm{ml}$ (Table 6). Among the two maturity stages, unripe fruits showed potent reducing power than that of the ripe fruits. The phytochemical analyses confirm that the unripe fruit extract was more abundant in phenolics and flavonoids than ripe fruits. The direct relationship of antioxidant activity with the reducing power of phytoconstituents was well studied on the orange pulp (Newhall variety) (35) and found that immature orange pulp has potent reducing power. Such a reduction in reducing capacity with maturity might be correlated with the reduction of phenolic contents and flavonoids in the fruits (36). Various other studies explain that the antioxidant activity attributed to reducing power could be affected by stages of maturity, geographical origin or cultivar, harvest time, storage time (37), storage conditions, temperature $(38,39)$ or exogenous usage of chemicals (40).

The reducing power indicates the capacity of a reducing agent to donate electrons and convert free radicals in to more stable form (41). The reducing power of wild mango, especially unripe fruit extract, was found to be higher which give emphasis to its enormous antioxidant potential. The results point out that methanol extract of $S$. pinnata fruits might 
Table 1. Total antioxidant activity of methanol extracts of unripe and ripe fruits of S. pinnata.

\begin{tabular}{|c|c|c|c|c|c|c|}
\hline \multirow{2}{*}{ Standard/sample } & \multicolumn{6}{|c|}{ Concentration $(\mu \mathrm{g} / \mathrm{ml})$} \\
\hline & 25 & 50 & 75 & 100 & 125 & 150 \\
\hline Ascorbic acid & $18.33 \pm 0.25^{\mathrm{a}}$ & $40.86 \pm 0.80^{\mathrm{a}}$ & $58.60 \pm 0.10^{\mathrm{a}}$ & $71.23 \pm 0.11^{\mathrm{a}}$ & $83.60 \pm 0.26^{\mathrm{a}}$ & $92.26 \pm 0.30^{\mathrm{a}}$ \\
\hline Unripe fruits & $16.94 \pm 0.15^{\mathrm{b}}$ & $39.91 \pm 0.16^{\mathrm{a}}$ & $57.06 \pm 0.12^{\mathrm{b}}$ & $70.51 \pm 0.42^{\mathrm{a}}$ & $81.98 \pm 0.23^{b}$ & $90.43 \pm 0.35^{b}$ \\
\hline Ripe fruits & $9.53 \pm 0.45^{\mathrm{c}}$ & $21.56 \pm 0.51^{\mathrm{b}}$ & $29.83 \pm 0.76^{\mathrm{c}}$ & $40.36 \pm 0.55^{\mathrm{b}}$ & $50.80 \pm 0.26^{\mathrm{c}}$ & $58.83 \pm 0.47^{c}$ \\
\hline
\end{tabular}

Values are mean of triplicate \pm S.D. Superscripts with the same letters within each column are not significantly different at $p<0.05$.

Table 2. Reducing power of methanol extracts of unripe and ripe fruits of S. pinnata.

\begin{tabular}{|c|c|c|c|c|c|c|}
\hline \multirow{2}{*}{ Standard/ sample } & \multicolumn{6}{|c|}{ Concentration $(\mu \mathrm{g} / \mathrm{ml})$} \\
\hline & 25 & 50 & 75 & 100 & 125 & 150 \\
\hline Ascorbic acid & $31.13 \pm 0.25^{\mathrm{a}}$ & $58.90 \pm 0.10^{\mathrm{a}}$ & $74.65 \pm 0.13^{a}$ & $86.80 \pm 0.10^{\mathrm{a}}$ & $97.18 \pm 0.10^{\mathrm{a}}$ & $100.00 \pm 0.00^{\mathrm{a}}$ \\
\hline Unripe fruits & $27.10 \pm 0.20^{\mathrm{b}}$ & $42.40 \pm 0.21^{\mathrm{b}}$ & $54.36 \pm 0.13^{\mathrm{b}}$ & $66.56 \pm 0.14^{\mathrm{b}}$ & $78.63 \pm 0.20^{\mathrm{b}}$ & $89.42 \pm 0.18^{\mathrm{b}}$ \\
\hline Ripe fruits & $16.50 \pm 0.43^{c}$ & $28.43 \pm 0.40^{c}$ & $40.46 \pm 0.51^{\mathrm{c}}$ & $54.33 \pm 0.32^{\mathrm{c}}$ & $60.56 \pm 0.45^{\mathrm{c}}$ & $68.30 \pm 0.60^{c}$ \\
\hline
\end{tabular}

Values are mean of triplicate \pm S.D. Superscripts with the same letters within each column are not significantly different at $P<0.05$.

be converted the radical species into stable form and inhibited radical chain reaction. Previous study also showed the direct correlation between antioxidant activities and reducing power (42). Hence, reducing capacity may be taken as an important indicator of potent antioxidant capacity.

\section{DPPH radical scavenging activity}

DPPH radical-scavenging (Table 3) effect of methanol extracts of $S$. pinnata fruits was concentrationdependent mode and had an $\mathrm{IC}_{50}$ value of 72.23 and $97.5 \mu \mathrm{g} / \mathrm{ml}$ for the unripe and ripe fruits respectively, and that of ascorbic acid was $41 \mu \mathrm{g} / \mathrm{ml}$ (Table 6). The DPPH radical scavenging analysis clearly showed a significant difference (Table 3) in the inhibition of radicals by unripe and ripe fruit extracts. The increased activity of unripe fruits might be due to the occurrence of several antioxidants and thus indicated its good antioxidant potential $(26,43)$. Previous studies showed that, the DPPH radical scavenging activity of pomegranate aril was decreased with ripening (44). Lowered radical inhibition ability with ripening might be attributed to reduction in total phenolics, conversion of anthocyanins and other biochemical changes (45).

DPPH radical scavenging is used as a good in vitro model to measure the antioxidant activity of phytoconstituents in a short time. Electron donors in the extracts could reduce the radical to a stable diamagnetic molecule and it could be visualized by purple to yellow colour change (2). In the present study, scavenging of DPPH radical by the methanol extract of fruits of $S$. pinnata was lower than that of ascorbic acid. However, the extract exhibited appreciable scavenging activity, especially the unripe fruits and therefore, significant correlation between DPPH radical scavenging capacity and phenolic and tannin contents might be existed (2).

\section{Nitric oxide scavenging activity}

The results of this assay, as important as other radical scavenging activities of the extracts, was given in Table 4 . Nitric oxide scavenging capacity of the extracts and the reference compound was increased with increasing concentrations. The 50\% $\left(\mathrm{IC}_{50}\right)$ of radicals was scavenged by unripe fruit extract at a concentration of $83.25 \mu \mathrm{g} / \mathrm{ml}$, while that of the ripe fruit extract was $144 \mu \mathrm{g} / \mathrm{ml}$ (Table 6). Results of the study revealed that the unripe fruit extract found to be a better scavenger of nitric oxide than ripe fruit extract and significant difference ( $p<$ 0.05 ) was detected among three experimental conditions (unripe fruit extract, ripe fruit extract, and ascorbic acid). It is well known that continuous production of nitric oxide in mild quantities, lead to vascular collapse, whereas chronic expression leads to various carcinomas and inflammatory condition though it is a signalling molecule (46). Peroxynitrite

Table 3. DPPH radical scavenging activity of methanol extracts of unripe and ripe fruits of S. pinnata.

\begin{tabular}{|c|c|c|c|c|c|c|}
\hline \multirow{2}{*}{ Standard/ sample } & \multicolumn{6}{|c|}{ Concentration $(\mu \mathrm{g} / \mathrm{ml})$} \\
\hline & 25 & 50 & 75 & 100 & 125 & 150 \\
\hline Ascorbic acid & $38.40 \pm 0.34^{\mathrm{a}}$ & $56.43 \pm 0.23^{\mathrm{a}}$ & $69.18 \pm 0.16^{\mathrm{a}}$ & $80.21 \pm 0.25^{\mathrm{a}}$ & $92.58 \pm 0.07^{a}$ & $100.00 \pm 0.00^{\mathrm{a}}$ \\
\hline Unripe fruits & $18.18 \pm 0.17^{\mathrm{b}}$ & $34.72 \pm 0.14^{\mathrm{b}}$ & $51.68 \pm 0.27^{\mathrm{b}}$ & $63.99 \pm 0.20^{\mathrm{b}}$ & $76.06 \pm 0.22^{b}$ & $87.95 \pm 0.10^{\mathrm{b}}$ \\
\hline Ripe fruits & $11.36 \pm 0.50^{\mathrm{c}}$ & $25.63 \pm 0.55^{\mathrm{c}}$ & $38.53 \pm 0.45^{\mathrm{c}}$ & $51.46 \pm 0.41^{\mathrm{c}}$ & $59.26 \pm 0.47^{c}$ & $67.53 \pm 0.55^{c}$ \\
\hline
\end{tabular}

Values are mean of triplicate \pm S.D. Superscripts with the same letters within each column are not significantly different at $P<0.05$.

Table 4. Nitric oxide scavenging activity of methanol extracts of unripe and ripe fruits of $S$. pinnata.

\begin{tabular}{lcccccc}
\hline \multirow{2}{*}{ Standard/ sample } & \multicolumn{5}{c}{ Concentration $(\boldsymbol{\mu g} / \mathbf{m l})$} \\
\cline { 2 - 7 } & 25 & 50 & 75 & 100 & 125 & 150 \\
\hline Ascorbic acid & $22.13 \pm 0.32^{\mathrm{a}}$ & $38.56 \pm 0.20^{\mathrm{a}}$ & $53.50 \pm 0.26^{\mathrm{a}}$ & $61.36 \pm 0.20^{\mathrm{a}}$ & $70.36 \pm 0.20^{\mathrm{a}}$ & $78.43 \pm 0.05^{\mathrm{b}}$ \\
\hline Unripe fruits & $20.97 \pm 0.10^{\mathrm{a}}$ & $34.75 \pm 0.20^{\mathrm{b}}$ & $46.20 \pm 0.08^{\mathrm{b}}$ & $58.22 \pm 0.25^{\mathrm{b}}$ & $70.96 \pm 0.12^{\mathrm{a}}$ & $81.56 \pm 0.25^{\mathrm{a}}$ \\
\hline Ripe fruits & $12.46 \pm 0.40^{\mathrm{b}}$ & $25.86 \pm 0.70^{\mathrm{c}}$ & $33.26 \pm 0.47^{\mathrm{c}}$ & $39.10 \pm 0.55^{\mathrm{c}}$ & $45.53 \pm 0.40^{\mathrm{b}}$ & $51.43 \pm 0.40^{\mathrm{c}}$ \\
\hline Values are mean of triplicate \pm S.D. Superscripts with the same letters within each column are not significantly different at $P<0.05$.
\end{tabular}

Table 5. $\mathrm{H}_{2} \mathrm{O}_{2}$ scavenging activity of methanol extracts of unripe and ripe fruits of S. pinnata.

\begin{tabular}{|c|c|c|c|c|c|c|}
\hline \multirow{2}{*}{ Standard/ sample } & \multicolumn{6}{|c|}{ Concentration $(\mu \mathrm{g} / \mathrm{ml})$} \\
\hline & 25 & 50 & 75 & 100 & 125 & 150 \\
\hline Ascorbic acid & $32.53 \pm 0.30^{\mathrm{a}}$ & $54.49 \pm 0.39^{a}$ & $68.50 \pm 0.20^{\mathrm{a}}$ & $81.31 \pm 0.10^{\mathrm{a}}$ & $88.23 \pm 0.21^{\mathrm{a}}$ & $96.70 \pm 0.20^{\circ}$ \\
\hline Unripe fruits & $23.33 \pm 0.17^{\mathrm{b}}$ & $38.65 \pm 0.08^{b}$ & $55.62 \pm 0.22^{\mathrm{b}}$ & $67.41 \pm 0.37^{\mathrm{b}}$ & $78.39 \pm 0.22^{b}$ & $87.04 \pm 0.07^{\mathrm{b}}$ \\
\hline Ripe fruits & $18.54 \pm 0.33^{c}$ & $32.31 \pm 0.33^{c}$ & $52.38 \pm 0.40^{c}$ & $65.53 \pm 0.40^{c}$ & $71.70 \pm 0.43^{c}$ & $76.43 \pm 0.37$ \\
\hline
\end{tabular}

Values are mean of triplicate \pm S.D. Superscripts with the same letters within each column are not significantly different at $P<0.05$. 
Table 6. The $\mathrm{IC}_{50}$ values $(\mu \mathrm{g} / \mathrm{ml})$ of methanol extract of $S$. pinnata fruits and reference compound ascorbic acid.

\begin{tabular}{|c|c|c|c|}
\hline Assays & Unripe fruits & Ripe fruits & Ascorbic acid \\
\hline Total antioxidant activity & $65^{\mathrm{a}}$ & $124.25^{\mathrm{b}}$ & $63.25^{\mathrm{a}}$ \\
\hline Reducing power & $66^{\mathrm{b}}$ & $92.5^{c}$ & $41.75^{\mathrm{a}}$ \\
\hline DPPH scavenging & $72.23^{\mathrm{b}}$ & $97.5^{c}$ & $41.0^{\mathrm{a}}$ \\
\hline Nitric oxide scavenging & $83.25^{\mathrm{b}}$ & $144.0^{\mathrm{c}}$ & $68.5^{\mathrm{a}}$ \\
\hline Hydrogen peroxide scavenging & $66.75^{\mathrm{b}}$ & $72.25^{\mathrm{c}}$ & $45.00^{\mathrm{a}}$ \\
\hline
\end{tabular}

Superscripts with the same letters within each row are not significantly different at $P<0.05$.

Table 7. Total phenolic, flavonoid and tannin contents of methanol extract of $S$. pinnata fruits.

\begin{tabular}{cccc}
\hline Extract & $\begin{array}{c}\text { Total phenolics } \\
\text { (mg GAE/100 g DW) }\end{array}$ & $\begin{array}{c}\text { Total flavonoids } \\
\text { (mg QEE/100 g DW) }\end{array}$ & Total tannins (mg TAE/100 g DW) \\
\hline Unripe fruits & $384.24 \pm 0.18$ & $217.46 \pm 0.36$ & $72.28 \pm 0.23$ \\
\hline Ripe fruits & $243.13 \pm 0.29$ & $183.87 \pm 0.64$ & $95.60 \pm 0.25$ \\
\hline
\end{tabular}

Values are mean of triplicate \pm S.D.

(ONOO-), a highly reactive species, would be formed when NO reacts with superoxide radical, this in turn increases the toxic effect (47). The present study proved that the fruit extracts of $S$. pinnata have good nitric oxide scavenging effect, especially the unripe fruit extract. Recent studies showed that phenolic compounds have greater NO scavenging capacity in surroundings with acidic $\mathrm{pH}$ (48). This may account for the higher nitric oxide radical scavenging activity of the unripe fruit extract.

\section{Hydrogen peroxide scavenging activity}

The $\mathrm{H}_{2} \mathrm{O}_{2}$ scavenging by methanol extracts of fruits of $S$. pinnata and the reference compound ascorbic acid were depicted in Table 5 . The $\mathrm{IC}_{50}$ values of unripe and ripe fruit extracts were 66.75 and $72.25 \mu \mathrm{g} / \mathrm{ml}$ respectively, and that of ascorbic acid was $45 \mu \mathrm{g} / \mathrm{ml}$ (Table 6). $\mathrm{H}_{2} \mathrm{O}_{2}$ is an oxidant which is being continuously formed in tissues as by-products of metabolism. As shown in Table 5, $S$. pinnata fruit extracts showed an effective $\mathrm{H}_{2} \mathrm{O}_{2}$ scavenging in a dose-dependent mode and have significant scavenging potential as reference compound. The scavenging of $\mathrm{H}_{2} \mathrm{O}_{2}$ by plant extracts may be attributed to their phenolics, which can donate electrons to $\mathrm{H}_{2} \mathrm{O}_{2}$ and neutralize it to water and the higher $\mathrm{H}_{2} \mathrm{O}_{2}$ scavenging activity of the unripe fruit extract was also correlated with amounts of total phenolics (49). It has been reported that hydrogen peroxide radical scavenging properties of medicinal fruits such as Terminalia chebula Retz. T. bellirica (Gaertn.) Roxb. and Emblica officinalis Gaertn. were found to be negligible, whereas that of $S$. pinnata showed a promising scavenging effect on $\mathrm{H}_{2} \mathrm{O}_{2}$ radical (50).

\section{Total phenolic, flavonoid and tannin contents}

Antioxidant activity is a fundamental property vital for life. A direct relationship exists between many of the biological processes, such as antiaging, anticarcinogenicity and antimutagenicity and the presence of natural antioxidants $(28,51,52)$ of either exogenous or endogenous origin. The phytoconstituents such as phenolics, flavonoids and tannins contribute much to the antioxidant activity of fruits and vegetables $(28,52-55)$, which are good source of natural antioxidants. The phenolic compounds are the principal antioxidants, which scavenge free radicals, are widely distributed in plant kingdom (56).
Total phenolic content (Table 7) of wild mango was $384.24 \pm 0.18$ and $243.13 \pm 0.29 \mathrm{mg} \mathrm{GAE} / 100 \mathrm{gm}$ DW of the unripe and ripe fruit extracts respectively. A significant difference in phenolic contents was found in ripe and unripe fruits of $S$. pinnata in the present study. This might be associated with the increased polyphenol oxidase activity at mature stages $(57,58)$, thereby an apparent decrease was observed at the ripe fruit extract. The polymerization of leucoanthocyanidins and hydrolysis of the arabinose ester of hexahydrodiphenic acid also contribute much to the reduction in phenolic contents at later stages of fruit development (59). The fruit phenolic content can be affected not only by ripeness but also by other factors such as species, variety, harvesting time, geography, cultivation, climate and storage conditions (60-62).

The results of the occurrence of flavonoids and tannins in relation to the fruit ripening is presented in Table 7. Flavonoids are benzopyrone derivatives, abundant in plants and shows antioxidant activity. The flavonoid contents of unripe and ripe fruits of $S$. pinnata was $217.46 \pm 0.36$ and $183.87 \pm 0.64 \mathrm{mg}$ QE/100 gm DW of the extracts respectively. Flavonoids are good for health because of their antioxidant and anti-inflammatory activities. These molecules hinder the low-density lipoprotein (LDL), the oxidation and facilitate cardioprotection (63). Present study indicates that the ample amounts of flavonoids in S. pinnata fruits substantiates its use as natural antioxidants. Additionally, the total tannin content of the unripe and ripe fruit extracts was $72.28 \pm 0.23$ and $95.60 \pm 0.25 \mathrm{mg} \mathrm{TAE} / 100 \mathrm{~g} \mathrm{DW} \mathrm{mg}$ of the extracts respectively (Table 7).

Flavonoids and tannins have found effective antioxidant activity through multiple actions such as scavenging of reactive oxygen species (ROS), hindering the pathways of ROS generation, chelating trace metals and reduce oxidizing radicals by donating hydrogen and their effects on human nutrition and health $(51,64)$. In the present study, the highest flavonoid contents were found in unripe fruit extract and highest tannin contents were observed in ripe fruit extracts. Earlier reports showed that various flavonoids converted to complex molecules such as tannins and lignins as the fruits became ripen (65). Consequently, due to change in phenolics, flavonoids and tannins with maturity, the ripe fruits of $S$. pinnata possessed 
relatively lower quantities of flavonoids and phenolics as well as greater amount of tannins than unripe fruits.

In the present study, the highest total antioxidant activity, reducing power and different radical scavenging activities were displayed by unripe fruit extract. Therefore, the study revealed that there was a significant relationship between antioxidant capacity and phenolics and flavonoids contents as it was higher in the unripe fruit extract of S. pinnata.

\section{Conclusion}

The extracts of Spondias pinnata fruits, especially unripe extracts showed antioxidant potential which are as good as to that of reference compound ascorbic acid. From the present study, it could be recommended that ripening stage of $S$. pinnata fruits had effects on the amount of total phenolics, flavonoids and tannin contents which may directly be correlated with the antioxidant activity. In addition to phenolics, flavonoids and tannins, the raw fruits of $S$. pinnata (both ripe and unripe) may contain good amount of vitamin C (ascorbic acid) and hence, the actual antioxidant potential of these fruits may be higher than that obtained in the present study. Finally, we could suggest that $S$. pinnata fruits at any stage of maturity, especially the unripe fruits, be a good source of natural antioxidants and initiatives would be taken to procure the nutritional and medicinal benefits of this fruit.

\section{Acknowledgements}

The authors are thankful to the authorities of St. Thomas College, Palai and Carmel College Mala for providing facilities for the smooth conduct of the research.

\section{Authors' contributions}

Both the authors have contributed equally to work.

\section{Conflict of interests}

The authors declare that we have no conflict of interest.

\section{References}

1. Sarvajeet SG, Narendra T. Reactive oxygen species and antioxidant machinery in abiotic stress tolerance in crop plants. Plant Physiol Biochem. 2010;48:909-30. https://doi.org/10.1016/j.plaphy.2010.08.016

2. Mani B, Thomas TD. Evaluation of the antioxidant potential of Pittosporum dasycaulon Miq. stem bark. Food Sci Biotechnol. 2014;23:539-45. https://doi.org/10.1007/s10068-014-0074-8

3. Aruoma OI. Free radicals, oxidative stress, and antioxidants in human health and disease. J Am Oil Chem Soc. 1998;75:199212. https://doi.org/10.1007/s11746-998-0032-9
4. Botterweck AAM, Verhagen H, Goldbohm RA, Kleinjans J, Van den Brandt PA. Intake of butylated hydroxyanisole and butylated hydroxytoluene and stomach cancer risk: Results from analyses in the Netherlands cohort study. Food Chem Toxicol. 2000;38:599-605. https://doi.org/10.1016/S02786915(00)00042-9

5. Block G, Patterson B, Subar A. Fruit, vegetables and cancer prevention: A review of the epidemiological evidence. Nutr Cancer. 1992;18:1-29. https://doi.org/10.1080/01635589209514201

6. Leja M, Mareczek A, Ben J. Antioxidant properties of two apple cultivars during long-term storage. Food Chem. 2003;80:303-07. https://doi.org/10.1016/S0308-8146(02)00263-7

7. Li HB, Cheng KW, Wong CC, Fan KW, Chen F, Jiang Y. Evaluation of antioxidant capacity and total phenolic content of different fractions of selected microalgae. Food Chem 2007;102:771-76.

https://doi.org/10.1016/j.foodchem.2006.06.022

8. Stangeland T, Remberg SF, Lye KA. Total antioxidant activity in 35 Ugandan fruits and vegetables. Food Chem. 2009;113:85 91.https://doi.org/10.1016/j.foodchem.2008.07.026

9. Tavares L, Carrilho D, Tyagi M, Barata D, Serra AT, Duarte CMM et al. Antioxidant capacity of Macaronesian traditional medicinal plants. Molecules. 2010;15:2576-92. https://doi.org/10.3390/molecules15042576

10. Lamien-Meda A, Lamien CE, Compaore MMY, Meda RNT, Kiendrebeogo M, Zeba B, Millogo JF, Nacoulma OG. Polyphenol content and antioxidant activity of fourteen wild edible fruits from Burkina Faso. Molecules. 2008;13:581-94. https://doi.org/10.3390/molecules13030581

11. Sasidharan N. Flowering Plants of Kerala ver. 2.0 [DVD]. Thrissur: Kerala Forest Research Institute; 2011.

12. Satpathy G, Tyagi YK, Gupta RK. Preliminary evaluation of nutraceutical and therapeutic potential of raw Spondias pinnata Kurz., an exotic fruit of India. Food Res Int. 2011;44:2076-87. https://doi.org/10.1016/j.foodres.2011.01.040

13. Tandon S, Rastogi RP. Studies on the chemical constituents of Spondias pinnata. Planta Med. 1976;29:190-22. https://doi.org/10.1055/s-0028-1097651

14. Jain P, Hossain KR, Mishu TR, Reza HM. Antioxidant and antibacterial activities of Spondias pinnata Kurz. Leaves. $\begin{array}{llll}\text { European J Med Plants. 2014;4:183-95 } & \text {. }\end{array}$ https://doi.org/10.9734/EJMP/2014/7048

15. Hazra B, Biswas S, Mandal N. Antioxidant and free radical scavenging activity of Spondias pinnata. BMC Complement Altern Med. 2008;8:63.https://doi.org/10.1186/1472-6882-8-63

16. Hazra B, Sarkar R, Mandal N. Spondias pinnata stem bark extract lessens iron overloaded liver toxicity due to hemosiderosis in Swiss albino mice. Ann Hepatol. 2013;12:12329. https://doi.org/10.1016/S1665-2681(19)31394-8

17. Ghate NB, Hazra B, Sarkar R, Mandal N. In-vitro anticancer activity of Spondias pinnata bark on human lung and breast carcinoma. $\quad$ Cytotechnology. 2014;66:209-18. https://doi.org/10.1007/s10616-013-9553-7

18. Li R, Yang J-J, Song X-Z, Wang Y-F, Corlett RT, Xu Y-K, Hu H-B Chemical Composition and the Cytotoxic, Antimicrobial and Anti-Inflammatory Activities of the Fruit Peel Essential Oil from Spondias pinnata (Anacardiaceae) in Xishuangbanna, Southwest China. $\quad$ Molecules. 2020;25:343. https://doi.org/10.3390/molecules25020343

19. Prieto P, Pineda M, Aguilar M. Spectrophotometric quantitation of antioxidant capacity through the formation of a phosphomolybdenum complex: Specific application to the determination of vitamin E. Annals Biochem. 1999;269:33741.https://doi.org/10.1006/abio.1999.4019

20. Yen GG, Duh PD. Antioxidative properties of methanolic extracts from peanut hulls. J Am Oil Chem Soc. 1993;70:383-86 https://doi.org/10.1007/BF02552711

21. Thomas S, Mani B. Chemical composition, antibacterial and antioxidant properties of essential oil from the rhizomes of Hedychium forrestii var. palaniense Sanoj and M. Sabu. Indian J Pharm Sci. 2016;78:452-57. https://doi.org/10.4172/pharmaceutical-sciences.1000139 
22. Johnson EI. The quantitative analysis of Drugs- by D.C. Garratt. J Pharm Pharmacol. 1964;16:772. https://doi.org/10.1111/j.2042 7158.1964.tb07408.x

23. Ruch RJ, Cheng SJ and Klaunig JE. Prevention of cytotoxicity and inhibition of intracellular communication by antioxidan catechins isolated from Chinese green tea. Carcinogenesis. 1989;10:1003-08. https://doi.org/10.1093/carcin/10.6.1003

24. Olayinka AA, Anthony IO. Preliminary phytochemical screening and in- vitro antioxidant activities of the aqueous extract of Helichrysum longifolium DC. BMC Complement Altrn Med. 2010;10:21. https://doi.org/10.1186/1472-6882-10-21

25. Zhishen J, Mengcheng T, Jianming W. The determination of flavonoid contents in mulberry and their scavenging effects on superoxide radicals. Food Chem. 1999;64:555-59. https://doi.org/10.1016/S0308-8146(98)00102-2

26. Mandal P, Misra TK, Ghosal M. Free radical scavenging activity and phytochemical analysis in the leaf and stem of Drymaria diandra Blume. Int J Integr Biol. 2009;7:80-84.

27. Lee JC, Kim HR, Kim J, Jang YS. Antioxidant property of an ethanol extract of the stem of Opuntia ficus-indica var. sabote. J Agric Food Chem. 2002;50:6490-96. https://doi.org/10.1021/jf020388c

28. Velioglu YS, Mazza G, Gao L, Oomah BD. Antioxidant activity and total phenolics in selected fruits, vegetables and grain products. J Agric Food Chem. 1998;10:4113-17. https://doi.org/10.1021/jf9801973

29. Sum PC, Khoo HE, Azlan A. Comparison of nutrient composition of ripe and unripe fruits of Nypa fruticans. Fruits. 2013;68:491-98.https://doi.org/10.1051/fruits/2013089

30. Havsteen BH. The biochemistry and medical significance of the Flavonoids. Pharmacol. Therapeut. 2002;96:67202.https://doi.org/10.1016/S0163-7258(02)00298-X

31. Petti S, Scully C. Polyphenols, oral health and disease: a review. J Dentistry. 2009;37:413-23.
20. https://doi.org/10.1016/j.jdent.2009.02.003

32. Adeolu AA, Florence OJ, Anthony JA, Patrick JM. Antioxidant activities and phenolic contents of the methanol extracts of the stems of Acokanthera oppositifolia and Adenia gummifera. BMC Complement Altern Med. 2008;8:54.https://doi.org/10.1186/1472-6882-8-54

33. Abdalbasit AM, Ramlah MI, Maznah I, Norsharina I Antioxidant activity and phenolic content of phenolic rich fractions obtained from black cumin (Nigella sativa) seedcake. Food Chem. 2009;116:306-12. https://doi.org/10.1016/j.foodchem.2009.02.051

34. Ke-Xue Z, Cai-Xia L, Xiao-Na G, Wei P, Hui-Ming Z. Antioxidant activities and total phenolic contents of various extracts from defatted wheat germ. Food Chem. 2011;126:1122-26. https://doi.org/10.1016/j.foodchem.2010.11.144

35. Huang R, Xia R, Hu L, Lu Y, Wang M. Antioxidant activity and oxygen scavenging system in orange pulp during fruit ripening and maturation. Sci Hort. 2007;113:166-72. https://doi.org/10.1016/j.scienta.2007.03.010

36. Iqbal S, Bhanger MI. Effect of season and production location on antioxidant activity of Moringa oleifera leaves grown in Pakistan. J Food Comp Anal. 2006;19:544-51. https://doi.org/10.1016/j.jfca.2005.05.001

37. Van-Der Sluis A, Dekker M, de Jager A, Jongen W. Activity and concentration of polyphenolic antioxidants in apple: Effect of cultivar, harvest year and storage conditions. J Agric Food Chem. 2001;49:3606-13.https://doi.org/10.1021/jf001493u

38. Ayala-Zavala JF, Wang SY, Wang CY, lez-Aguilar GA. Effect of storage temperatures on antioxidant capacity and aroma compounds in strawberry fruit. LWT-Food Sci Technol. 2004;37:687-95. https://doi.org/10.1016/j.lwt.2004.03.002

39. Kondo S, Kittikorn M, Kanlayanarat S. Preharvest antioxidant activities of tropical fruit and the effect of lower temperature storage on antioxidant and jasmonates. Postharvest Biol Tec. 2005;36:309-18.

https://doi.org/10.1016/j.postharvbio.2005.02.003

40. Wang LJ, Chen SJ, Kong WF, Li SH, Archbold DD. Salicylic acid pretreatment alleviates chilling injury and affects the antioxidant system and heat shock proteins of peaches during cold storage. Postharvest Biol Tec. 2006;41:244-51. https://doi.org/10.1016/j.postharvbio.2006.04.010

41. Ganu GP, Jadhav SS, Deshpande AD. Antioxidant and antihyperglycemic potential of methanolic extract of bark of Mimusops elengi L. in mice. Res J Pharm Biol Chem Sci. 2010;1:67-77.

42. Yildirim A, Mavi A, Kara AA. Determination of antioxidant and antimicrobial activities of Rumex crispus L. extracts. J Agric Food Chem. 2001;49:4083-9.https://doi.org/10.1021/jf0103572

43. Gordon MH. The mechanism of the antioxidant action in-vitro. In: Hudson BJF, editor. Food antioxidants. London: Elsevier 1999. p. 1-18.https://doi.org/10.1007/978-94-009-0753-9_1

44. Kulkarni AP, Aradhya SM. Chemical changes and antioxidant activity in pomegranate arils during fruit development. Food Chem. https://doi.org/10.1016/j.foodchem.2004.09.029

45. Bashir HA, Abu-Goukh AA. Compositional changes during guava fruit ripening. Food Chem. 2003;80:557-63. https://doi.org/10.1016/S0308-8146(02)00345-X

46. Tylor BS, Kion YM, Wang QI, Sharpio RA, Billiar TR, Geller DA. Nitric oxide down regulates hepatocyte-inducible nitric oxide synthase gene expression. Arch Surg. 1997;132:1177-83. https:// doi.org/10.1001/archsurg.1997.01430350027005

47. Huie RE, Padmaja S. The reaction of NO with superoxide. Free Radic Res Commun. 1993;18:195-99. https://doi.org/10.3109/10715769309145868

48. Noh, KS, Yang MO, Cho EJ. Nitrite scavenging effect of Umbelliferae. Korean J Food Cookery Sci. 2002;18:8-12.

49. Ebrahimzadeh MA, Nabavi SF, Nabavi SM. Antioxidant activities of methanol extract of Sambucus ebulus L. flower. $\begin{array}{llll}\text { Pak J Biol } & \text { Sci. } & \text { 2009;12:447-50 }\end{array}$ https://doi.org/10.3923/pjbs.2009.447.450

50. Hazra B, Sarkar R, Biswas S, Mandal N. Comparative study of the antioxidant and reactive oxygen species scavenging properties in the extracts of the fruits of Terminalia chebula Terminalia bellirica and Emblica officinalis. BMC Complement Altern Med. 2010;10:20. https://doi.org/10.1186/1472-6882-10-20

51. Cook NC, Samman S. Flavonoids-chemistry, metabolism, cardioprotective effects and dietary sources. J Nutr Biochem. 1996;7:66-76. https://doi.org/10.1016/0955-2863(95)00168-9

52. Magrone T, Candore G, Caruso C, Jirillo E, Covelli V. Polyphenols from red wine modulate immune responsiveness: Biological and clinical significance. Curr Pharm Des. 2008;14:2733-48. https://doi.org/10.2174/138161208786264098

53. Kidd PM. Bioavailability and activity of phytosome complexes from botanical polyphenols: the silymarin, curcumin, green tea and grape seed extracts. Altern Med Rev. 2009;14:226-46.

54. Adams LS, Zhang Y, Seeram NP, Heber D, Chen S. Pomegranate ellagitannin-derived compounds exhibit antiproliferative and antiaromatase activity in breast cancer cells in-vitro. Cancer Prev Res. 2010;3:108-13. https://doi.org/10.1158/19406207.CAPR-08-0225

55. Huang WY, Cai YZ, Zhang Y. Natural phenolic compounds from medicinal herbs and dietary plants: potential use for cancer prevention. Nutr Cancer. 2010;62:1-20. https://doi.org/10.1080/01635580903191585

56. Prior RL, Cao G. Antioxidant phytochemicals in fruits and vegetables-Diet and health implications. Hort Sci. 2000;35:588 92. https://doi.org/10.21273/HORTSCI.35.4.588

57. Parr AJ, Bolwell PAJ. Phenols in the plant and in man: The potential for possible nutritional enhancement of the diet by modifying the phenols content or profile. J Sci Food Agric. 2000;80:985-12. 0010(20000515)80:7<985::AID-JSFA572>3.0.CO;2-7

58. Rop O, Sochor J, Jurikova T, Zitka O, Skutkova H, Mlcek J, et al. Effect of five different stages of ripening on chemical compounds in medlar (Mespilus germanica L.). Molecules. 2011;16:74-91. https://doi.org/10.3390/molecules16010074

59. Stanislaw L. Determination of the degree of polymerization of leucoanthocyanidins. Phytochemistry. 1968;7:665-67. https://doi.org/10.1016/S0031-9422(00)88246-1 
60. Wang SY, Lin HS. Antioxidant activity of fruits and leaves of blackberry, raspberry, and strawberry varies with cultivar and developmental stages. J Agric Food Chem. 2000;48:140-46. https://doi.org/10.1021/jf9908345

61. Iqbal S, Bhanger MI. Effect of season and production location on antioxidant activity of Moringa oleifera leaves grown in Pakistan. J Food Comp Anal. 2006;19:544-51. https://doi.org/10.1016/j.jfca.2005.05.001

62. Kondakova V, Tsvetkov I, Batchvarova R, Badjakov I, Dzhambazova T, Slavov S. Phenol compounds-qualitative index in small fruits. Biotechnol Biotech Eq. 2009;23:1444-48. https://doi.org/10.2478/V10133-009-0024-4
63. Kondo K, Hirano R., Matsumoto A, Igarashi O, Itakura $\mathrm{H}$ Inhibition of LDL oxidation by cocoa. Lancet. 1996;348:1514 18. https://doi.org/10.1016/S0140-6736(05)65927-2

64. Kalim MD, Bhattacharyya D, Banerjee A, Chattopadhyay S. Oxidative DNA damage preventive activity and antioxidant potential of plants used in Unani system of medicine. BMC $\begin{array}{llll}\text { Complement } & \text { Altern } & \text { Med. } & \text { 2010;10:77. }\end{array}$ https://doi.org/10.1186/1472-6882-10-77

65. Ben-ahmed C, Ben-Rouina B, Sensoy S, Boukhriss M. Saline water irrigation effects on fruit development, quality and phenolic composition of virgin olive oils, cv. Chemlali. J Agric Food Chem. 2009;57:2803-11. https://doi.org/10.1021/jf8034379 